\title{
PROFESSIONAL COMPETENCES OF A BEGINNING MASTER OF VOCATIONAL EDUCATION AND ITS REFLECTION
}

\section{Lýdia ČELLÁROVÁ}

\begin{abstract}
In the article we point actual requirements for professional competences of a teacher, acquaint with proposal of professional standards and competences of beginning master of vocational education and brief results of the survey, in which students of the last year of practical preparation pedagogy study rate their competences.
\end{abstract}

Key words: professional competences, master of vocational training, reflection, survey

\section{PROFESIJNÉ KOMPETENCIE ZAČÍNAJÚCEHO MAJSTRA ODBORNEJ VÝCHOVY A ICH REFLEXIA}

Resumé: V predkladanom príspevku poukazujeme na aktuálne požiadavky na profesijné kompetencie učitel'a, oboznamujeme s návrhom profesijných štandardov a kompetencii začinajúceho majstra odbornej výchovy a so stručnými výsledkami prieskumu, v ktorom hodnotili svoje kompetencie študenti posledného ročníka štúdia učitel'stva praktickej prípravy.

Kl'účové slová: profesijné kompetencie, majster odbornej výchovy, reflexia, prieskum

\section{1 Úvod}

V ostatnom čase sa v súvislosti so školskou reformou na Slovensku častejšie, ako predtým, venuje na stránkach odbornej tlače, $\mathrm{v}$ prostriedkoch masovej komunikácie, ako aj v elektronických médiách zvýšená pozornost' učitel'skej profesii, predpokladom a podmienkam na výkon tejto profesie, ktoré sú zastrešované pojmami kompetencie, spôsobilosti, zručnosti, ale aj kvalifikácia.

Školská reforma na Slovensku, reflektujúca potreby súčasnej trhovej ekonomiky a trendy vzdelávania v štátoch Európskej únie, výrazne ovplyvnila požiadavky nielen na kurikulárnu transformáciu školstva, na rozvoj kl'účových kompetencií, ale aj na kvalitu práce učitel'a, na jeho kompetencie, $v$ konečnom dôsledku na systematiku pregraduálnej prípravy, na permanentné, celoživotné vzdelávanie a na profesionalizáciu učitel’a.

\section{Požiadavky na učitel'a v kontexte celospoločenských zmien \\ Mnohé teoretické práce a novodobé medzinárodné programové dokumenty (napr. Delorsov koncept štyroch pilierov vzdelávania: učit' sa poznávat', učit' sa byt', učit' sa konat', učit' sa žit' spoločne s ostatnými (1996); Bolonská deklarácia (1999), požadujúca okrem iného zjednotenie stupňov vzdelávania; Memorandum celoživotného vzdelávania (Brusel 2000); Lisabonská stratégia EU (2000) zdôrazňujúca}

potrebu rozvoja klúčových kompetencií, Kodanská deklarácia (2002) zdôrazňujúca princípy celoživotného vzdelávania a profesionalizácie činností učitel'a) na jednej strane a národné projektové a legislatívne dokumenty (Milénium - Národný program výchovy a vzdelávania ... (2001), Nový školský zákon (2008) a Zákon o pedagogických zamestnancoch (2009)), zdôrazňujúce potrebu celoživotného vzdelávania pedagógov a vypracovania profilov pedagogických pracovníkov, štandardov na posudzovanie ich kompetencií, kariérneho systému, celkovej profesionalizácie učitel'ov na druhej strane, zdôrazňujú mimoriadne dôležité postavenie práve učitel'ov, ako profesijnej skupiny. Novodobý pohl'ad na učitel'a ako profesionála, požaduje nielen vysokú úroveň jeho sebauvedomenia, autonómie a sebakontroly pri vykonávaní profesie, ale aj vedomia a preživania príslušnosti $\mathrm{k}$ nej.

Ako uvádza V. Rosa (2003), je v procese reforiem školstva, orientovanom okrem kurikulárnej reformy na reformu postavenia a požiadaviek na učitel'a, na jeho vzdelávanie a zabezpečovanie podmienok profesijného rozvoja priorita, aktuálna pre svetový trend vzdelávania, čo bolo potvrdené aj na rokovaní svetového kongresu o vzdelávaní učitel'ov a ich úlohe vo vzdelávacej reforme (Santiago de Chile, 2001). 
Podla Európskej komisie (2002) bolo navrhnuté rozdelenie kompetencií učitel'a na:

- kompetencie vztahujúce sa na proces učenia (poznanie vstupných charakteristík žiaka a meniacich sa podmienok vyučovania)

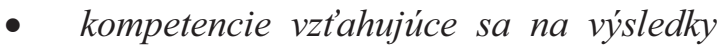
učenia, vychádzajúce najmä z klúčových kompetencií pre uplatnenie sa $\mathrm{v}$ spoločnosti 21. stor. (kompetencie k aktívnemu občianstvu, európanstvu a udržatel'nému rozvoju, celoživotného vzdelávania, digitálna gramotnost', schopnosti tvorivo riešit' problémy, komunikácia, kooperácia, kreativita a inovácie, motivácia k učeniu, kompetencie využívat' IKT, pracovat' v tíme, participovat' na tvorbe školského kurikula a jeho overovaní, kompetencie spolupráce s rodičmi a sociálnymi partnermi) (Kasáčová Kosová, 2006).

\section{Profesijný štandard začínajúceho majstra odbornej výchovy}

Dlhodobé diskusie odborníkov na rôznych fórach o tom, aké profesijné kompetencie by mal učitel' mat', sa na Slovensku dostávajú do fázy prijatia konkrétnych návrhov profesijných štandardov učitel'a, jeho kompetencií. Prijatím Zákona o pedagogických zamestnancoch a odborných zamestnancoch (24. 6. 2009) sa vytvorili podmienky na uvedenie štandardizácie učitel'skej profesie do praxe. Pre jednotlivé kategórie a stupne kariérového rastu boli v súlade s Koncepciou profesijného rozvoja učitel'ov v kariérnom systéme (2007) navrhnuté profesijné štandardy, vrátane štandardov pre majstrov odbornej výchovy.

Profesijný štandard, ako normativ, vymedzuje nevyhnutné profesijné kompetencie pre štandardný výkon pedagogického zamestnanca tromi široko koncipovanými dimenziami - orientáciou na žiaka, na vyučovaci proces ana sebarozvoj učitel'a v štruktúre klúčových a špecifických kompetencií. V profesijnom štandarde sú vymedzené kvalifikačné predpoklady, definovaný je komplex preukázatel'ných spôsobilostí - kompetencií v podobe vedomostí, zručností, postojov a tiež indikátory, ktorými je možné tieto kompetencie diagnostikovat' a hodnotit'.

Významným kvalitatívnym posunom v postavení majstra odbornej výchovy je možnost' jeho kariérneho rastu, tak ako v ostatných pracovných pozíciách pedagogických zamestnancov od začínajúceho majstra odbornej výchovy až po majstra odbornej výchovy s 2 . atestáciou.
Pre kategóriu majster odbornej výchovy v 1. kariérnom stupni - začínajúci majster odbornej výchovy bola navrhnutá nasledovná štruktúra profesijného štandardu :

\section{Kompetencie orientované na žiaka}

1.1 identifikovat' vývinové a individuálne charakteristiky žiaka - poznat zákonitosti psychického vývoja a osobitosti žiaka, poznat' metodiku ich identifikovania, akceptovat' individualitu žiaka bez predsudkov

1.2 identifikovat' psychické a sociálne faktory učenia sa žiaka - poznat' štýly učenia sa žiaka, poznat' metodiku ich identifikácie, metodiku identifikácie individuálnych edukačných potrieb, akceptovat' rôzne štýly učenia sa žiakov

1.3 identifikovat' sociokultúrny kontext rozvoja žiaka - poznat' odlišnosti kultúr v multikultúrnom prostredí žiaka a ich vplyv na žiaka, poznat' metodiku zist'ovania vplyvu sociokultúrneho prostredia na žiaka, akceptovat' odlišnosti bez predsudkov a stereotypov

2 Kompetencie orientované na edukačný proces

2.1 ovládat' obsah vyučovacích predmetov - mat' vedomosti a zručnosti $\mathrm{v}$ odbore vrátane interdisciplinárnych vzt’ahov, poznat' základné pedagogické dokumenty (ZPD)

2.2 schopnost' plánovat' a projektovat' vyučovanie - poznat' problematiku plánovania a projektovania vyučovania $\mathrm{v}$ kontexte $\mathrm{ZPD}$, vediet' plánovat' a projektovat' vyučovanie $\mathrm{v}$ kontexte ZPD, so štandardom stredoškolského odborného vzdelávania a klúčových kompetencií, vediet' individualizovat' plánovanie a projektovanie podl'a špeciálnych potrieb žiakov

2.3 schopnost' stanovit' ciele vyučovania orientované na žiaka - poznat' kritériá tvorby edukačných ciel'ov, vediet' vymedzit' ciele učenia sa žiakov, orientované na rozvoj kompetencií, akceptovat' špecifiká podmienok pri variovaní ciel'ov

2.4 schopnost' psychodidaktickej analýzy učiva - poznat' zákonitosti psychodidaktickej analýzy učiva vo vzt'ahu k ciel'om, aplikovat' postupy psychodidaktickej analýzy učiva (určenie základného a rozvíjajúceho učiva, ...), vediet' navrhnút' $\mathrm{k}$ ciel'om učebné činnosti, úlohy a kritériá úspešnosti

2.5 schopnost výberu a realizácie vyučovacích foriem a metód - poznat' metódy a formy podporujúce aktívne učenie sa žiakov, vediet' vybrat' adekvátne formy a metódy na realizáciu učebných činností, identifikovat' sa s vybranými formami a metódami 
2.6 schopnost' hodnotit' priebeh a výsledky vyučovania a učenia sa žiaka - poznat' spôsoby hodnotenia žiakov a ich psychodidaktické aspekty, vediet' stanovit' kritériá hodnotenia, vediet' hodnotit' v súlade $\mathrm{s}$ vekovými a individuálnymi zvláštnost'ami

2.7 schopnost' vytvárat' pozitívnu klímu triedy - poznat' význam a faktory jej vytvárania a ovplyvňovania, vhodnou komunikáciou vytvárat' pozitívnu pracovnú, emocionálnu a sociálnu klímu, akceptovat' klímu triedy, ako faktor úspešnosti vyučovania a rozvoja žiaka

2.8 schopnost' vytvárat' a využivivat' materiálne a technologické zázemie vyučovania - poznat' základné didaktické prostriedky (vrátane IKT), vediet' vybrat', navrhnút', vytvorit' a využit' vhodné didaktické prostriedky, mat' pozitívny vzt'ah k moderným učebným pomôckam

2.9 schopnost' ovplyvňovat' personálny rozvoj žiaka - poznat' stratégie a metódy personálneho rozvoja (sebauvedomenia, sebapoznania, sebahodnotenia, sebaúcty, sebadôvery, sebaregulácie a sebarealizácie), aplikovat' stratégie a metódy podl'a individuálnych potrieb žiaka, akceptovat' a oceňovat' personálne zručnosti žiaka

2.10 schopnost' rozvíjat' sociálne zručnosti - poznat' stratégie a metódy sociálneho rozvoja žiakov, vediet' aplikovat' stratégie a metódy sociálneho rozvoja žiakov (komunikácia, empatia, asertivita, vzájomná pomoc, kooperácia, prajnost'), vediet' akceptovat' a oceňovat' sociálne zručnosti žiaka

\subsection{1 schopnost' prevencie a nápravy} sociálno-patologických javov a porúch správania sa žiaka - poznat' spôsoby identifikácie a prevencie sociálno-patologických javov, vediet' didakticky zapracovat' do edukácie riziká sociálno-patologických javov, oceňovat' pozitívne prejavy v správaní žiaka

\section{Kompetencie sebarozvoja učitel'a}

3.1 schopnost' profesionálneho rastu a sebarozvoja - poznat vlastné dispozície, hodnoty, silné a slabé stránky, poznat' trendy vývoja spoločnosti a trendy $\mathrm{v}$ oblasti edukácie, vediet' reflektovat' a hodnotit' vlastnú činnost' $\mathrm{v}$ tímovej práci, vediet' stanovit' ciele profesijného rozvoja na základe vlastných vzdelávacích potrieb, využívat' v sebarozvoji IKT a cudzí jazyk

3.2 schopnost' identifikovat' sa s profesijnou rolou a školou - poznat' poslanie a ciele učitel'skej profesie, vystupovat' ako reprezentant profesie, poznat' sociálnych partnerov a možnosti komunikácie s nimi (Valent, 2009).

Sme toho presvedčenia, že profil absolventa študijného odboru učitel'stva praktickej prípravy by sa mal čo najviac približovat' uvedenej charakteristike profesijného štandardu začínajúceho majstra odbornej výchovy.

Základnou úlohou pre učitel'ov vysokej školy, participujúcich na pregraduálnej príprave budúceho majstra odbornej výchovy je pripravit' absolventov schopných projektovat', pripravovat', organizovat', diagnostikovat', vyhodnocovat' a modifikovat' vyučovací proces. Zaujímalo nás, ako hodnotia svoje rozvíjajúce sa pedagogické kompetencie budúci majstri odbornej výchovy na prahu vstupu do pedagogickej praxe, aká je účinnost' pregraduálnej prípravy, v ktorých oblastiach je potrebné zintenzívnit' pôsobenie na študentov.

\section{Prieskum profesijných kompetencií}

Pri koncipovaní prieskumu sme vychádzali $z$ navrhovaného štandardu profesijných kompetencií začinajúceho majstra odbornej výchovy a predpokladu, že tieto kompetencie respondenti mali možnost' rozvíjat' v rámci stredoškolského a vysokoškolského štúdia.

\section{Ciel' a metóda prieskumu}

Ciel'om prieskumu bolo zistit', ako hodnotia úroven̆ svojich doterajšich pedagogických kompetencií poslucháči posledného - tretieho ročnika učitel'stva praktickej prípravy, absolvujúci skladbu kurzov pedagogickopsychologického všeobecného základu, ako aj didaktiky odborných predmetov, didaktiky odborného výcviku pred nástupom do pedagogickej praxe, samostatného zabezpečovania vyučovacieho procesu.

Pre naše účely sme zostavili dotazník, vychádzajúci zo špecifikácie štandardu začinajúceho majstra odbornej výchovy. Špecifické spôsobilosti (vedomosti, zručnosti a postoje) v rámci kompetencií orientovaných na žiaka, na vyučovací proces a na sebarozvoj sme usporiadali do tabulky, v ktorej mali respondenti vyznačit' mieru osvojenia v stupnici od výborne po nedostatočne.

\section{Charakteristika prieskumnej vzorky}

Prieskum sme uskutočnili začiatkom šk. roku 2009/2010 na vzorke 120 poslucháčov externého 
štúdia učitel'stva praktickej prípravy FPV UMB $v$ Banskej Bystrici, z toho 54 mužov a 66 žien.

\section{Výsledky prieskumu}

Zaujímalo nás, aká je frekvencie hodnoteni jednotlivých stupňov. Po celkovom spočítani jednotlivých stupňov hodnotenia sme zistili, že najčastejšie respondenti hodnotili svoje profesijne kompetencie ako dobré (1138-krát, t.j. $31,61 \%$ ), následne vel'mi dobré (1027-krát, t.j. $28,53 \%$ ), dostatočné (683-krát, t.j. 18,97\%), výborné (522- krát, t.j. 14,5\%) a nedostatočné (522-krát, t.j. 6,39 \%). Pre nadobudnutie predstavy rozloženia hodnotení sledovaných kompetencií uvádzame ich $v$ tabul'ke 1.

$\mathrm{Na}$ základe tabul'kového hodnotenia sú evidentné výraznejšie rozdiely v kvalite jednotlivých kompetencií. Z kompetencií ako najkvalitnejšie osvojené hodnotili respondenti vlastnú odbornú pripravenost' nadobudnutú štúdiom na strednej škole, schopnosti objektivne hodnotit' vlastné dispozície, schopnosti vhodne komunikovat' a využivat' v sebarozvoji IKT. Naproti tomu za najmenej rozvinuté považovali využívanie cudzieho jazyka pre vlastný rozvoj, schopnosti uskutočnit' didaktickú analýzu učiva, s čím úzko súvisí (ako vyplýva z odpovedí) väčšina nepozná ani postup jej uskutočnenia, za nepostačujúcu hodnotia aj schopnost' pripravit' vyučovanie $v$ súlade $s$ individuálnymi potrebami žiakov.

V položkách 1-4 sme sledovali kompetencie orientované na žiaka. Z odpovedí vyplýva, že teoretické vedomosti o osobnosti žiaka hodnotili respondenti ako lepšie osvojené, než praktické uplatnenie teórie pri identifikácie štýlov učenia sa a vplyvu sociokultúrneho prostredia na vývin žiaka.

Úroveň teoretických pedagogickopsychologických vedomostí, ale aj schopností ich integrovane uplatňovat' pri riešení pedagogických a didaktických situácií sme sledovali v položkách 5-21. Respondenti najvyššie hodnotili úroven̆ stredoškolskej odbornej prípravy $(39,17 \%$ respondentov ju hodnotilo ako výbornú, 38,33\% ako vel'mi dobrú, 16,67\% ako dobrú), ako najhoršie respondenti hodnotili schopnosti projektovat' vyučovanie podl'a špeciálnych potrieb žiakov $(5,83 \%$ hodnotilo ako výborné, $12,5 \%$ ako vel'mi dobré, 31,67\% ako dobré, $40 \%$ ako nedostatočné a až $10 \%$ za nedostatočné). Z kompetencií súvisiacich s ciel'mi vzdelávania (položka 9-13) najpozitívnejšie hodnotili respondenti schopnost' vymedzit' edukačné ciele orientované na rozvoj kompetencií $(5,83 \%$ respondentov hodnotila ako výborné, $24,17 \%$ ako vel'mi dobré, $40,83 \%$ ako dobré, $24,17 \%$ ako dostatočné a $5 \%$ ako nedostatočné). Výrazné nedostatky označili v schopnosti uskutočnit' didaktickú analýzu učiva (1,67\% respondentov ich hodnotila ako výborné, $18,33 \%$ ako vel'mi dobré, $28,33 \%$ ako dobré, $31,67 \%$ ako dostatočné a $20 \%$ ako nedostatočné) a vedomosti o jej postupe (0,83\% respondentov ich hodnotila ako výborné, $20 \%$ ako vel'mi dobré, $35 \%$ ako dobré, 31,67 \% ako dostatočné a $12,5 \%$ ako nedostatočné). Uvedená skutočnost' naznačuje, že do budúcna bude potrebné zvýšenú pozornost' venovat' tejto fundamentálnej aktivite predikujúcej úspešnost' každého výchovného a vzdelávacieho pôsobenia nielen po stránke praktickej, ale aj teoretickej a publikovaním odborných príspevkov prispiet' $\mathrm{k}$ riešeniu uvedených nedostatkov, ktoré sa ukázali nielen v našom prieskume, ale aj v samotnej práci mnohých učitel'ov z praxe.

Z položiek 14-17 respondenti za najlepšie osvojené označili vedomosti o nemateriálnych didaktických prostriedkoch $(28,33 \%$ hodnotili ako výborné, $36,67 \%$ ako vel'mi dobré, $25 \%$ ako dobré, $9,17 \%$ ako dostatočné a $0,83 \%$ ako nedostatočné). Prinajmenej prekvapivé bolo zistenie, že najmenej sú schopní navrhnút' a vytvorit' moderné učebné pomôcky $(24,17 \%$ respondentov hodnotila ako výborné, 28,33\% ako vel'mi dobré, $28,33 \%$ ako dobré, $15 \%$ ako dostatočné a 4,17 \% ako nedostatočné).

$\mathrm{V}$ podskupine kompetencií 18-21 respondenti najvyššie hodnotili schopnost' vytvárat' pozitívnu klímu vhodnou komunikáciou (30\% respondentov ako výborné, 40,83\% ako vel'mi dobré, 25\% ako dobré a 4,17\% ako dostatočné). Najväčšie nedostatky pocitujú respondenti vo vedomostiach o spôsoboch prevencie sociálnopatologických javov (5\% respondentov hodnotilo ako výborné, 19,17 \% ako vel'mi dobré, 33,33\% ako dobré aj ako dostatočné a 9,17 \% ako nedostatočné), o stratégiách a metódach sociálneho rozvoja $(2,5 \%$ respondentov ako výborné, $15,83 \%$ ako vel'mi dobré, $46,67 \%$ ako dobré, $28,33 \%$ ako dostatočné a $6,67 \%$ ako nedostatočné).

Nakol'ko sa jedná o vážne spoločenské problémy, bolo by potrebné venovat' im v pregraduálnej príprave zvýšenú pozornost' najmä riešením modelových situácií, ktoré musia stredoškolskí učitelia $\mathrm{v}$ praxi často riešit’. 
Tabul'ka1 Prehl'ad hodnotenia kompetencii

\begin{tabular}{|c|c|c|c|c|c|c|c|}
\hline Položka & Spôsobilosti - kompetencie & $\begin{array}{l}0 \\
\stackrel{0}{0} \\
\text { 菅 }\end{array}$ & $\frac{0}{0} 0$ & $\frac{0}{0}$ & $\begin{array}{l}0 \\
0 \\
0 \\
0 \\
0 \\
0 \\
0 \\
0\end{array}$ & 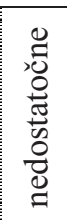 & $\frac{\bar{\partial}}{\circ}$ \\
\hline 1 & $\begin{array}{l}\text { poznám zákonitosti psychického vývoja a osobitosti žiaka strednej } \\
\text { školy }\end{array}$ & 4 & 43 & 47 & 22 & 4 & 120 \\
\hline 2 & poznám štýly učenia sa žiaka & 21 & 51 & 31 & 17 & 0 & 120 \\
\hline 3 & poznám metodiku identifikácie štýlov učenia sa žiakov & 6 & 30 & 52 & 24 & 8 & 120 \\
\hline 4 & $\begin{array}{l}\text { poznám metodiku zist’ovania vplyvu sociokultúrneho prostredia na } \\
\text { žiaka }\end{array}$ & 9 & 26 & 43 & 31 & 11 & 120 \\
\hline 5 & $\begin{array}{l}\text { mám vedomosti a zručnosti v odbore, vyštudovanom na strednej } \\
\text { škole }\end{array}$ & 47 & 46 & 20 & 7 & $\mathbf{0}$ & 120 \\
\hline 6 & $\begin{array}{l}\text { poznám základnú pedagogickú dokumentáciu (ZPD) odboru /-ov, } \\
\text { v ktorých sa môžem uplatnit’ ako pedagóg }\end{array}$ & 18 & 21 & 48 & 24 & 9 & 120 \\
\hline 7 & $\begin{array}{l}\text { viem ako plánovat' a projektovat' vyučovanie } \mathrm{v} \text { súlade so ZPD, } \\
\text { štandardom SOV a kl'účových kompetencí }\end{array}$ & 6 & 27 & 46 & 26 & 15 & 120 \\
\hline 8 & $\begin{array}{l}\text { viem ako individualizovat' plánovanie a projektovanie podla } \\
\text { špeciálnych potrieb žiakov }\end{array}$ & 7 & 15 & 38 & 48 & 12 & 120 \\
\hline 9 & poznám kritériá tvorby edukačných ciel’ov & 1 & 25 & 48 & 34 & 12 & 120 \\
\hline 10 & $\begin{array}{l}\text { viem vymedzit' ciele učenia sa žiakov, orientované na rozvoj } \\
\text { kompetencií }\end{array}$ & 7 & 29 & 49 & 29 & 6 & 120 \\
\hline 11 & poznám postup didaktickej analýzy učiva vo vztahu k ciel’om & 1 & 24 & 42 & 38 & 15 & 120 \\
\hline 12 & viem uskutočnit' didaktickú analýzu učiva & 2 & 22 & 34 & 38 & 24 & 120 \\
\hline 13 & $\begin{array}{l}\text { viem navrhnút' k edukačným ciel'om konkrétne učebné činnosti, } \\
\text { úlohy a kritériá ich hodnotenia }\end{array}$ & 6 & 43 & 26 & 34 & 11 & 120 \\
\hline 14 & poznám metódy a formy podporujúce aktívne učenie sa žiakov & 16 & 51 & 35 & 17 & 1 & 120 \\
\hline 15 & poznám nemateriálne didaktické prostriedky (vrá & 34 & 44 & 30 & 11 & 1 & 120 \\
\hline 16 & $\begin{array}{l}\text { viem zvolit', navrhnút', vytvorit' a využit' vhodné materiálne } \\
\text { didaktické prostriedky }\end{array}$ & 31 & 38 & 32 & 17 & 2 & 120 \\
\hline 17 & viem navrhnút' a vytvorit' moderné učebné pomôcky & 29 & 34 & 34 & 18 & 5 & 120 \\
\hline 18 & $\begin{array}{l}\text { dokážem vhodnou komunikáciou vytvárat' pozitívnu klímu v } \\
\text { kolektíve }\end{array}$ & 36 & 49 & 30 & 5 & $\mathbf{0}$ & 120 \\
\hline 19 & poznám stratégie a metódy personálneho rozvoja žiaka & $\mathbf{0}$ & 21 & 53 & 34 & 12 & 120 \\
\hline 20 & poznám stratégie a metódy sociálneho rozvoja žiakov & 3 & 19 & 56 & 34 & 8 & 120 \\
\hline 21 & $\begin{array}{l}\text { poznám spôsoby identifikácie a prevencie sociálno-patologických } \\
\text { javov }\end{array}$ & 6 & 23 & 40 & 40 & 11 & 120 \\
\hline 22 & poznám vlastné dispozície, hodnoty, silné a slabé stránky & 39 & 48 & 29 & 2 & 2 & 120 \\
\hline 23 & poznám trendy vývoja spoločnosti a trendy v oblasti edukácie & 5 & 39 & 43 & 30 & 3 & 120 \\
\hline 24 & viem reflektovat' a hodnotit' vlastnú činnost' $v$ tímovej práci & 26 & 43 & 41 & 10 & $\mathbf{0}$ & 120 \\
\hline 25 & viem si stanovit' konkrétne ciele môjho profesijného rozvoja & 37 & 43 & 33 & 7 & $\mathbf{0}$ & 120 \\
\hline 26 & využívam v sebarozvoji IKT & 47 & 33 & 31 & 7 & 2 & 120 \\
\hline 27 & využívam v sebarozvoji cudzí jazyk & 10 & 18 & 22 & 31 & 39 & 120 \\
\hline 28 & poznám poslanie a ciele učitel'skej profesie & 26 & 43 & 35 & 16 & 0 & 120 \\
\hline 29 & poznám funkcie majstra odbornej výchovy & $\mathbf{3 0}$ & 46 & 31 & 12 & 1 & 120 \\
\hline 30 & vystupujem ako budúci reprezentant učitel'skej profesie & 12 & 33 & 39 & 20 & 16 & 120 \\
\hline
\end{tabular}

V skupine kompetencií orientovaných na sebarozvoj učitel'a najpozitívnejšie hodnotili respondenti poznanie vlastných dispozicii, hodnôt, silných a slabých stránok (32,5\% ako výborné, $40 \%$ ako vel'mi dobré, $24,17 \%$ ako dobré, $1,67 \%$ ako dostatočné a 1,67 \% ako nedostatočné), ciel'avedomost' v profesijnom rozvoji $(30,83 \%$ ako výborné, $35,83 \%$ ako 
vel'mi dobré, $27,5 \%$ ako dobré a 5,83\% ako dostatočné). Nedostatky pocitujú poznatkoch $o$ trendoch vývoja spoločnosti a trendoch $v$ oblasti edukácie $(4,17 \%$ respondentov ako výborné, 32,5\% ako vel'mi dobré, 35,83\% ako dobré, $25 \%$ ako dostatočné a 2,5 \% ako nedostatočné). Ďalšími pozitívne hodnotenými sú schopnosti využivat'v sebarozvoji IKT $(39,17 \%$ ako výborné, $27,5 \%$ ako vel'mi dobré, $25,83 \%$ ako dobré a 5,83 \% ako dostatočné a 1,67 \% ako nedostatočné). $\mathrm{Na}$ druhej strane respondenti výrazne negatívne hodnotili využivanie cudzieho jazyka v sebarozvoji $(8,33 \%$ ako výborné, $15 \%$ ako vel'mi dobré, 18,33\% ako dobré a 25,83\% ako dostatočné a 32,5 \% ako nedostatočné). Hodnotenie kvality využívania cudzieho jazyka nie je pre nás prekvapujúce vzhl'adom na možnosti a úroveň výuky cudzích jazykov na mnohých stredných odborných školách, ako aj skutočnost', že študenti sledovaného študijného odboru nemajú možnost' ani v rámci vysokoškolského štúdia absolvovat' cudzí jazyk, nakol'ko tento $\mathrm{v}$ učebnom pláne absentuje. Poznanie odborného cudzieho jazyka je v súčasnosti pre profesiu učitel'a teoretických a najmä praktických odborných predmetov nevyhnutnost'ou, aby dokázal aktuálne prenášat' poznatky o nových materiáloch, strojoch a technológiách do prípravy absolventov pre úspešné uplatnenie sa na súčasnom a hlavne budúcom trhu práce.

\section{Záver}

Súčasné obdobie výrazných zmien v spoločnosti, vyžaduje od učitel'ov všetkých stupňov a typov škôl vysokú mieru zodpovednosti, aktivity, tvorivosti, permanentné vzdelávanie, hodnotenie výsledkov vlastnej vyučovacej činnosti a učebnej práce žiakov. Prieskumom, ktorý bol príležitost'ou sebareflexie respondentov, sme zistili rezervy $\mathrm{v}$ profesijnej príprave budúcich učitel'ov praktickej prípravy, na základe ktorých je žiaduce upravit' tak obsah, ako aj proces vzdelávania.

Vzhl'adom k tomu, že prieskum sa uskutočnil $\mathrm{v}$ úvodnej etape sledovania problému na malej vzorke respondentov z jednej školy, boli výsledky spracované stručne, bez podrobnejšej štatistickej analýzy. V d'alšej fáze riešenia výskumného problému plánujeme rozšírit' okruh respondentov aj $z$ iných vysokých škôl pripravujúcich na profesijnú dráhu budúcich majstrov odbornej výchovy a podrobit' výsledky podrobnej štatistickej analýze.

\section{Literatúra}

[1] KASÁČOVÁ, B. - KOSOVÁ, B. Kompetencie a spôsobilosti učitel'a - európske trendy a slovenský prístup. In: Profesijný rozvoj učitel'a. Prešov : Metodicko-pedagogické centrum, 2006, s. 36-48. ISBN 80-8045-431-0.

[2] ROSA, V. Učitel' a jeho profesia - problémy a perspektívy. In: Pedagogická revue, Ročník 55, Č́́slo 3, s. 216-230. ISSN 1335-1982.

[3] VALENT, M. Návrh profesijných štandardov učitel'ov - majster odbornej výchovy (Diskusia). In: Pedagogické rozhlady. Ročník 18, Číslo 1, Príloha. ISSN 1335-0404.

[4] Vyhláška MŠ SR č. 41/1996 Z. z. o odbornej a pedagogickej spôsobilosti pedagogických zamestnancov v znení neskorších predpisov.

PaedDr. Lýdia Čellárová, PhD.

Katedra techniky a technológií

Fakulta prírodných vied

Univerzita Mateja Bela

Tajovského 40

97401 Banská Bystrica

Tel: +421 0484467219

E-mail: cellar@fpv.umb.sk 